\title{
Availability of Moisture in Aggregates of Various Sizes in a Typical Ultisol and a Typical Oxisol of Puerto Rico
}

\author{
Raúl Pérez Escolar and M. A. Lugo López ${ }^{1}$
}

\section{INTRODUCTION}

Ultisols are mineral soils with clayey horizons and low percentage base saturation, usually less than 35 percent. They have clayskins and a welldeveloped structure with a cation-exchange capacity ranging between 16 and 24 meq. $/ 100 \mathrm{~g}$. of dry soil (8). They have developed under conditons of high rainfall. Although they are partly laterized they lack an oxic horizon, but they have an argillic horizon. The Oxisols are soils with an A horizon the total exchange capacity of which is less than $16 \mathrm{meq} . / 100 \mathrm{~g}$. where bases are less than 12 meq. They do not exhibit clay films and the structure is either weak or nonexistent (8). These soils exhibit a high degree of aggregation and the aggregates have generally a high degree of stability $(5) .^{2}$ Both Ultisols and Oxisols show a high infiltration rate (1) and it has been claimed that they have a low available water-supplying power.

This paper reports on a laboratory study intended to determine the available water capacity of various-sized aggregates as compared with the whole soils.

\section{PROCEDURE}

Soil samples were taken at selected locations typical of sites previously mapped and described as Catalina and Cialitos soils. The samples were taken from the topmost 12 inches in each case.

The samples were air-dried and then a portion of each was kept as whole soils while the rest was separated by dry-sieving into the following aggregate sizes: $>5,5-3,3-2$, and $2-1 \mathrm{~mm}$. The water retained at $1 / 3$ and 15 atm. was then determined for each aggregate size and for the whole soil. Water retained at $1 / 3 \mathrm{~atm}$. was determined by pressure-plate extraction, while that retained at $15 \mathrm{~atm}$. was determined by using a pressure membrane. The available water is considered to be the difference between the water retained at $1 / 3$ and $15 \mathrm{~atm}$.

The pipette method as modified by Kilmer and Alexander $(8)$ was used in determining particle-size distribution. The chromic acid reduction method proposed by Walkley and Black (9) was used for the determination of

1 Associate Soil Scientist and Soil Scientist, respectively, Agricultural Experiment Station, Mayagüez Campus, University of P.R., Río Piedras, P.R.

3 Italic numbers in parentheses refer to Literature Cited, p. 117. 
organic matter. The method proposed by Jeffries (2), namely, the potassium oxalate-oxalic acid-magnesium ribbon procedure, was used in the determination of free iron oxides. The ammonium acetate method developed by Schollenberger and Simon ( $(y)$ was used for determining the cation-exchange capacity.

\section{CHARACTERIZATION OF THE SOILS}

The Catalina and Cialitos soils are rather extensive in the Central Mountainous Region of Puerto Rico. Both are deep, acid soils with low inherent fertility. Catalina is a Tropectic, clayey, oxidic, isohyperthermic Oxisol. Cialitos is a Orthoxic, clayey, oxidic isohyperthermic Ultisol.

Table 1 gives data that partly characterize the soils. The soils have about the same clay content. Cialitos is slightly higher in silt and correspondingly lower in sand. The organic-matter levels are about the same. There are

TABLE 1.-Data on particle size distribution, organic-matter content, free iron oxides, and cation exchange capacity of Catalina and Cialitos soils

\begin{tabular}{l|r|r}
\hline \multicolumn{1}{c|}{ Item } & Catalina & Cialitos \\
\hline Sand, percent & 13.2 & 10.4 \\
Silt, percent & 23.9 & 28.5 \\
Clay, percent & 62.9 & 61.1 \\
Organic matter, percent & 3.5 & 3.2 \\
Free iron oxides, percent & 18.2 & 13.0 \\
Cation exchange capacity, meq./100 g. dry soil & 12.1 & 20.5 \\
\hline
\end{tabular}

marked differences, however, in content of free iron oxides, Catalina clay having more than 18 percent, while Cialitos clay has only 13. Striking differences are evident as to cation-exchange capacity with Cialitos clay values of over 20 meq. while the corresponding values for Catalina clay are only about $12 \mathrm{meq}$. These differences have been discussed elsewhere by Pérez Escolar and Lugo López (6). They account for these differences on the basis of the poorer crystallization of the kaolinite clay in the Cialitos soil and also on the higher iron oxide content of Catalina clay.

\section{MOISTURE AVAILABILITY IN RELATION TO AGGREGATE SIZE}

Data on water retained at $1 / 3$ and $15 \mathrm{~atm}$. of pressure and available water content are given in table 2 . In both soils the larger aggregates hold about the same amount of moisture at $1 / 3 \mathrm{~atm}$. as does the whole soil. As the aggregate size decreases the water retained at this tension increases to levels higher than those of the whole soil. When the moisture retained at $15 \mathrm{~atm}$. is considered, the larger aggregates are able to hold larger amounts than the whole soil; then a gradual decrease in registered. Thus, as aggregate size 
decreases the moisture retained at $15 \mathrm{~atm}$. of tension also decreases. As a result of this situation there is a clear tendency for available water to increase as aggregate size decreases. While in both cases the available water is of the order of 13.6 or 13.7 percent for the whole soil, it is only 10.7 and 10.8 for the aggregates larger than $5 \mathrm{~mm}$. It then increases steadily to levels of 15.7 and 17.7 in the $2-$ to $1-\mathrm{mm}$. size aggregates. These last values represent an increase of around 22 percent over the whole soil.

This situation can perhaps be attributed to the fact that the larger aggregates have many more fine pores and less large ones than the smaller

TABLE 2.-Relationship between aggregate size, the moisture retained at $1 / 8$ and 15 atm., and available water

\begin{tabular}{|c|c|c|c|}
\hline \multirow{2}{*}{ Aggregate size, $\mathrm{mm}$. } & \multicolumn{2}{|c|}{$\begin{array}{l}\text { Moisture retained at indicated } \\
\text { tension, percent }\end{array}$} & \multirow{2}{*}{$\begin{array}{c}\text { Percent available } \\
\text { water }\end{array}$} \\
\hline & $3 \hat{s} \mathrm{~atm}$. & $15 \mathrm{~atm}$. & \\
\hline \multicolumn{4}{|c|}{ Catalina clay } \\
\hline $\begin{array}{c}>5 \\
5-3 \\
3-2 \\
2-1 \\
\text { Whole soil }\end{array}$ & \begin{tabular}{l|l|}
36.5 & \\
37.6 & \\
38.3 \\
38.7 \\
37.9
\end{tabular} & $\begin{array}{l}25.7 \\
24.8 \\
24.5 \\
23.0 \\
24.3\end{array}$ & \begin{tabular}{l|l|}
10.8 & \\
12.8 \\
13.8 \\
15.7 \\
13.6
\end{tabular} \\
\hline \multicolumn{4}{|c|}{ Cialitos clay } \\
\hline $\begin{array}{c}>5 \\
5-3 \\
3-2 \\
2-1 \\
\text { Whole soil }\end{array}$ & \begin{tabular}{l|l|}
32.7 & \\
35.0 & 35.8 \\
37.3 & \\
33.8 &
\end{tabular} & $\begin{array}{l}22.0 \\
21.8 \\
19.5 \\
19.6 \\
20.1\end{array}$ & $\begin{array}{l}10.7 \\
13.2 \\
16.3 \\
17.7 \\
13.7\end{array}$ \\
\hline
\end{tabular}

aggregates, and the adhesion forces retaining moisture at higher tensions are more effective. In the smaller aggregates larger voids have been created in-between the aggregates themselves. Thus, the adhesion forces are not as effective in holding moisture at high tensions such as those that develop when permanent wilting is approached. Perhaps the opposite situation is applicable when considering moisture retention at lower tensions, such as $1 / 3 \mathrm{~atm}$. Less moisture is drained from the larger pores between smaller aggregates at such low tensions.

The authors have recently found that Mabi clay, a Vertisol from eastcentral Puerto Rico, retains almost 40 percent of moisture when tensions in the vicinity of permanent wilting develop. The presence of extremely fine pores accounts for such a high moisture value. Mechanical creation of 
aggregates in this soil with subsequent stabilization by the action of free iron oxides have been conducive to higher cane and sugar yields. It is apparent that moisture availability has increased with the creation of larger voids in-between soil aggregates. ${ }^{3}$

Extremely fine pores have also been observed in most of the soils of the Lajas Valley (4). If at least intermediate-size pores are mechanically created, water availability in those soils would be increased.

\section{SUMMARY}

Data are presented in this paper on the availability of moisture in Catalina clay, an Oxisol, and Cialitos clay, an Ultisol. The soils are very high in clay content and fairly high in organic-matter content. Catalina clay is high in free iron oxides with $\mathbf{1 8 . 2}$ percent, while Cialitos clay has 13 percent. Striking differences are evident as to cation exchange capacity with values of over 20 meq. for Cialitos and only around 12 meq. for Catalina.

Both soils have low available water-supplying power. However, when the individual aggregates are considered, the smaller ones retain larger volumes of available water than the larger ones. This is so because moisture retained at higher tensions decreases with decreasing aggregate size, while that retained at lower tensions increases with decreasing aggregate size. These results are explained on the basis of the larger volume of small pores in larger aggregates and the larger voids created in-between smaller aggregates.

\section{RESUMEN}

En este estudio se presentan datos sobre la humedad disponible en el suelo Catalina arcilloso, un Oxisol, y en el Cialitos arcilloso, un Ultisol. Ambos suelos tienen un contenido de arcilla sumamente alto $\mathrm{y}$ uno de materia orgánica bastante alto. El suelo Catalina arcilloso es alto en óxidos de hierro libres alcanzando un nivel de $\mathbf{1 8 . 2}$ por ciento, mientras que en el Cialitos éstos sólo alcanzan un 13 por ciento.

Ambos suelos tienen una baja capacidad para suministrar el agua en estado disponible. Sin embargo, cuando se toman en cuenta los agregados individualmente, se observa que los más pequeños retienen un volumen mayor de agua disponible que los más grandes. Esto es así, porque la humedad retenida a tensiones altas decrece cuando disminuye el tamaño de los agregados, mientras que la retenida a tensiones bajas aumenta cuando disminuye el tamaño de los agregados. Los resultados se atribuyen al hecho de que los agregados grandes tienen un volumen mayor de poros pequeños, mientras que entre los agregados pequeños se forman poros más grandes.

s Pérez-Escolar, R. and Lugo-López, M. A., unpublished data, Department of Agronomy and Soils, 1967. 


\section{LITERATURE CITED}

1. Bonnet, J. A., and Lugo-López, M. A., The rate of infiltration of lateritic soils, J. Agr. Univ. P.R. $\$ 6$ (2): 161-6, 1952.

2. Jeffries, C. D., A rapid method for the removal of free iron oxides prior to petrographic analysis, Soil Sci. Soc. Amer. Proc. 11: 211-12, 1946.

3. Kilmer, V. J., and Alexander, J. T., Methods of making mechanical analyses of soils, Soil Sci. 68: 15-24, 1949.

4. Lugo-López, M. A., Pérez-Escolar, R., Acevedo, G., and Juárez, Jr., J., Nature and Properties of Major Soils of Lajas Valley, Bull. 149, Agr. Expt. Sta., Univ. P.R., 1959.

5. Pérez-Escolar, R., and Lugo-López, M. A., Nature of aggregation in tropical soils of Puerto Rico, J. Agr. Univ. P.R. 52(3): 227-232, 1962.

6. Pérez-Escolar, R., and Lugo-Ĺbez, M. A., Influence of degree of clay mineral crystallization and free iron oxide content on the cation exchange capacity of Catalina and Cialitos soils, J. Agr. Univ. P.R., submitted in 1967.

7. Schollenberger, C. J., and Simon, R. H., Determination of exchange capacity and exchangeable bases in soil: Ammonium acetate method, Soil Sci. 59: 13-23, 1945.

8. Soil Survey staff, Soil Conservation Service, Soil Classification, a comprehensive System, 7th Approximation, U.S.D.A., 1960.

9. Walkley, A., and Black, T. A., An examination of the Degtjareff method for determining soil organic matter and a proposed modification of the chromic acid titration method, Soil Sci. s7: 29-8, 1934. 